Projections • 14. New Uses for Old Rivers: Rediscovering Urban Waterways

\title{
Metropolis on the water: Varieties of development logics along the Seine
}

\author{
Yonah Freemark ${ }^{1}$ \\ ${ }^{1}$ PhD Candidate, Department of Urban Studies and Planning, MIT
}

\section{MIT Press}

Published on: Dec 20, 2019

DOI: https://doi.org/10.1162/00c13b77.ea8fcc5a

License: Creative Commons Attribution 4.0 International License (CC-BY 4.0). 


\section{ABSTRACT}

Scholars writing about the influence of the "neoliberal turn" suggest that, in response to global competition and a declining welfare state, cities have committed to using urban development projects for the purpose of investment attraction through spatially isolated interventions, particularly on key sites such as riverfronts. But is that really the case, or do project programming and design offer opportunities to combat inequality and increase links to the surrounding city? I explore this question through a study of postwar waterside development in Paris, examining planning documents and statements by government representatives. While officials have promoted their city's global status, I show that they have also increasingly emphasized the provision of affordable housing; meanwhile, they have encouraged new approaches to urban design that prioritize local needs over those of tourists and create new links between existing neighborhoods. This suggests that Paris' projects reflect a diversity of development logics - that is, goals with respect to certain planning policies - including some conducive to promoting social equity and community cohesion. This finding challenges expectations about project creation as commonly understood through the lens of the neoliberal turn. It suggests that contemporary urbanism is not converging to a uniform, regressive outcome. I identify institutional and political changes—respectively, the devolution of power to the local government in 1977 and the election of left-wing councils beginning in 2001—as the primary explanations for Paris' history.

\section{Introduction}

A large theoretical literature argues that the form and programming of major urban development projects, which shape the form, function, and social composition of cities worldwide, reflect the "neoliberal turn.” This line of thought suggests that in the face of global economic changes since the 1970s that prioritize marketoriented reforms such as financialization and privatization, projects are converging to a framework that promotes competitivity and economic growth, ignoring the needs of lower-income residents in favor of tourists and the wealthy. This focus is manifested through urban design that isolates projects from surrounding neighborhoods. Formerly industrial waterfronts are particularly prone to be impacted by this approach thanks to their preexisting isolation, limited potential for community resistance, and possibility for attracting high rents thanks to their natural settings.

To what extent is there evidence for a convergence toward inequality-increasing, secluded projects? Or, conversely, are there opportunities for political agents to engage varying development logics to accomplish multiple objectives - including some that promote social and physical integration with the rest of the city? This paper addresses these questions by examining the history, programming, and urban design of key riverfront developments completed in the city of Paris since the 1960s. In doing so, I demonstrate that major projects are not converging either programmatically or physically in line with expectations of those who point to the neoliberal turn's influence. An emphasis on economic growth through tertiary development predated the 
neoliberal turn, and more recent projects completed under left-wing local governments, in fact, incorporate increased social housing and create links between neighborhoods.

The five large, mixed-use developments reviewed here-Front-de-Seine, Bercy-Rapée, Citroën-Cévennes, Bercy, and Paris Rive Gauche-will collectively encompass about 15,000 housing units and 1.3 million $\mathrm{m}^{2}$ of offices when completed. They are very visible, accounting for $6.3 \mathrm{~km}$ of waterfront along the Seine River. They are a manifestation of the city's post-industrial transformation and the product of choices by decision makers working across multiple governmental levels, from various political stripes. Their changing development patterns are reflective of an altered understanding of what the riverfront is for; its purpose has shifted from a useful site for large offices and tourism, disconnected from the rest of the city, to a key mechanism to increase social equity and improve community connections.

To develop my analysis, I reviewed planning documents, officials' statements, site plans, and architectural diagrams, and I conducted site visits. Most documents were produced by the Atelier parisien d'urbanisme (APUR, the City of Paris planning agency), whose reports are overseen by elected officials and typically produced following city-council decisions or mayoral orders. By understanding how political and planning actors publicly justified their choices, we gain a sense of what motivated them, such as social or economic priorities. By exploring urban design, we can track the degree to which projects are oriented toward isolation from the city or integration into it.

I catalogue project features temporally to highlight change over time, and I show how they can be understood as manifestations of what I refer to as development logics, which are exploited by political officials. These reflect project-planning goals, and are related to broader orientations that are not exclusively limited to development, such as towards the market, social needs, and the environment. These logics coexist (they are available to political actors throughout the time period analyzed), but their individual influence waxes and wanes depending on institutional structure and the ideological preferences of those in power. I use in-depth document analysis, which includes coding of key words and highlighting of themes that are or are not mentioned, to identify 12 distinct development logics and their relative importance in project planning.

This paper proceeds as follows. First, I draw out the scholarly claim that recent mixed-use urbanism, informed by the neoliberal turn, is chiefly concerned with meeting the needs of higher-income constituencies, offering sites for popular attractions, and promoting city competitivity. Second, I sketch out the five case-study projects. Third, I describe project evolution in terms of the values each prioritizes, using document review to identify the development logics officials promoted in making choices on programming, urban design, and waterfront links. While revelatory, this analytical approach has limitations. I discuss these in the concluding section of the paper, where I also offer suggestions for new realms of research. 


\section{Project-based urban development}

The projects I examine are enormous and often contentious investments. Because of their scale, the years of planning required to undertake them, and their visible waterfront sites, they provide insight into the dominant thinking about how urban policy should be conducted, whose interests and needs should be prioritized, and how cities should be designed. These characteristics make such projects a frequent target of research that identifies them as manifestations of the neoliberal turn in the global economy. This approach suggests that local actors structure developments to prioritize wealth and speculation, and are designed as spaces of exclusion, closed off from the surrounding city. But, as I show in this section, this framework is limited and should be supplanted with a more nuanced view of project planning.

Much of the critical literature in urbanism is premised on the idea that urban development's emphasis shifted in line with the neoliberal turn. This turn, understood to have begun in the early 1970s, was the product of rising inflation and slowing growth, and was executed by governments that increasingly focused on global trade and financialization to boost the economy. At the same time, national governments evolved their policies from maximizing nationalized, evenly distributed resources to promoting metropolitan competitiveness (Brenner 2004). "Champion cities" now compete to build the national economy, in part through large, mixed-use developments, replacing comprehensive planning (which had recognized the need to serve members of many social classes) with individual investments (Pinson 2009).

Scholarship on these projects emphasizes their use as facilitators of competitiveness in the face of economic adjustment. Since the transition to a post-industrial economy left acres of "underused" city-center land (Savitch 1988), particularly along waterfronts, local governments could take advantage of the vacant space. Inspired by the perceived success of redevelopments such as Baltimore’s Harborplace and Bilbao’s Guggenheim Museum, city governments worldwide have worked to rebuild such sites into attractive places (Busquets and Correa 2006). In the process, urban design is harnessed for economic growth (Gospodini 2002). According to this school of thought, projects are a "means for generating future growth and for waging a competitive struggle to attract investment capital” and thus economic regeneration (Swyngedouw et al. 2002, 563), which is necessary for cities to increase their tax bases, jobs, and residents. Such investments are meant to build a city's status, overriding local concerns with the "imperatives of the global economy” (Lehrer and Laidley 2008, 794).

Many scholars portray these projects as peddling the interests of the wealthy—residents and tourists—-who partake in amenities like offices for financial enterprises, shopping malls, marinas, and aquariums (Jauhiainen 1995). In doing so, these investments reproduce urban inequality (Lehrer and Laidley 2008). Enright (2016) and Swyngedouw et al. (2002) argue that though redistributive elements such as affordable housing are sometimes mentioned during planning, these are in execution subordinated to demands of capital. The "growth machine” replaces old uses and spaces with “riverside gentrification” (Chang and Huang 2011). 
Some critics suggest that projects' urban design, reflecting the need to prioritize the needs of both consumerusers and property investors (rather than the public at large, as might have been the case in an era before the neoliberal turn), is opposed to the local and intentionally not integrated into surrounding neighborhoods. Local governments physically pull projects apart from the city, thereby creating spaces of exception that fail to address resident needs (Chang and Huang 2011). These projects give visitors the ability to get away, to "escape from everyday responsibilities” through spectacle (Stevens 2006, 200). Goss (1996, 241) playfully describes Baltimore’s waterfront as a “dream-house of contemporary consumer capitalism” where problems like racial discrimination, homelessness, and poverty are pushed under the rug.

The feasibility of altering the look and function of formerly industrial waterfronts is enhanced because of these areas' scale (where else can you find so much space without displacing existing residents?) and, often, their public ownership (Eidelman 2016). Waterfront development often engages significant government involvement, and when government ownership is unified, dramatic changes are possible (Eidelman 2018; Gordon 1997). With public land ownership, governmental actors can more easily develop land-use plans, direct the construction of individual buildings, and manage public spaces.

Much of the existing literature, then, advances several conclusions about how urban developments reflect, and reinforce, the neoliberal turn both in their programs and designs. The first is that projects largely prioritize economic growth by transforming (often public) land into private, rent-producing real estate that attracts speculative investment, while deemphasizing or eliminating space for low-income residents and users. Key to this logic are national governments that orient local spending for the purpose of achieving national growth goals (Brenner 2004). Second, this line of research indicates that these approaches are manifested in particular types of urban design, such as isolated developments featuring dramatic architecture and major attractions to bring in consumption-oriented tourists.

Whether these conclusions about the changing economy's impact on planning are convincing, however, requires additional empirical examination. Indeed, we should be skeptical of arguments that point to global economic changes as an explanation for new patterns of urbanity. First, evidence for the neoliberal turn's impact on development is less than overwhelming. Has neoliberalism actually altered how, and what kinds of, projects are built, and in what contexts? In France there is a long history of using public investment to promote markets and business that reaches well before neoliberalism or even deindustrialization (Pinson and Morel Journel 2016a). French governance has for decades retained a corporatist character that melds the public and private interest (Savitch 1988). This suggests that, at least in these contexts, critiques of neoliberalism often are simply using new terminology to critique pre-existing capitalist government-development relationships (Storper 2016). There is limited evidence for a clear epochal divide in property-led urban development in terms of political agendas, policy instruments, and systems of relations between actors (Pinson and Morel Journel 2016b). 
Relatedly, the frequently cited claim that the changing economy has been associated with a state rollback in planning and public investment is undermined by the fact that governments have actively increased spending on projects that support the largest cities, such as Paris (Crouch and Le Galès 2012). And that increased spending has not been devoted singlehandedly to the purpose of encouraging economic growth (this funding does not seem single-mindedly focused on regional competitivity). Indeed, it is difficult to reconcile the argument for the power of the neoliberal turn over urban affairs with the reality of significant increases in the number of funded French social housing units since the 1980s. Thus, if French dirigisme has hardly disappeared in general, in this paper I engage to ask how it has evolved in the context of specific projects in waterfront locations, where we might expect the greatest pressures for speculative investment.

Second, multiple avenues for urban development are open for city initiative. Much of the critical literature points to an almost omnipotent neoliberal political economy that structurally determines how cities invest. Some have appropriately articulated that neoliberalism as a concept is insufficient in understanding how cities make choices. Yet many of these arguments are deterministic, too, suggesting few opportunities for political or ideological divergence. For example, Le Galès (2016) points to what he claims are more important matters, such as clientelism. Storper $(2016,258)$ suggests that local policy is relatively irrelevant; cities "can at best act on the margins of these large-scale economic and societal changes and national policies.” He argues that public choices are largely converging in the West, not to some neoliberal goal, but responding in a way that he refers to as "pragmatically" to local characteristics such as population density, resident incomes, and geographical borders.

Through the case studies presented here, I offer evidence that reaffirms the contention that the neoliberal turn has had limited impact on urban development broadly, and waterfront redevelopment specifically. Yet I also argue that project programming and design are not deterministically produced by other forces, but rather are the result of altered prioritization of available development logics brought on by changes in both institutional structure and ruling political ideologies. I show that the riverfront projects in Paris have held consistently to certain objectives-including both economic development and social housing (the latter has become more influential) — throughout the period examined, putting in question the relevance of the neoliberal turn, and undermining claims of a new convergence toward speculation-focused ways of conducting urban development. Meanwhile, I demonstrate a clear move away from spaces of exception and isolation in urban design.

\section{Waterfront development in Paris: Five marquee projects}

I investigate the history, programmatic priorities, and design characteristics of the large, postwar, mixed-use, riverside projects in the French capital. Construction occurred throughout the Paris region during this period marked by city population loss and metropolitan growth. But I focus on waterfront sites rather than developments generally because of several shared characteristics when targeted for construction. They were each previously used for industrial or logistics uses. Most of the land they occupy was owned by governments directly or state-owned enterprises, such as the SNCF railway. Each is within a few miles of Paris' central 
areas, and though not within the center, each offers excellent access to it. They share the natural element of lining the Seine River. Together, these characteristics could make such sites ideal for governments to focus their efforts to enhance growth and build tourism (sites in far-off suburbs or within poor neighborhoods, on the other hand, seem a priori less relevant to the broader use of urban development as a tool for economic growth). Thus, these projects allow me to evaluate the two primary questions motivating this research: Whether urban development has been transformed by the neoliberal turn, and whether project planning is exclusionary and isolating in programming and design.

These pre-development characteristics — industrial uses, state ownership, and location within the same cityalso make it reasonable to consider the five projects together, collectively representing local urban policies. Under French law, the municipal council must approve project development plans (typically zones d'aménagement concerté, ZACs), which define future building type, location, and use. Most projects were developed by semi-public authorities called sociétés d'économie mixte (SEMs). Though SEMs incorporate capital from private and/or state-owned enterprises, in these cases they are controlled by city-appointed officials and can be viewed as extensions of local government; their primary interest when designing and executing projects, according to Nelson (2001), is not in profit-making but in fulfilling the goals of elected politicians. $\underline{1}$

Because planning and development of the projects I consider span from the 1950s to the present, changing local power is key to evaluating design. Before 1977, the city was under the direct control of the national government. In that year, Jacques Chirac, a member of the center-right RPR political party, was elected in the city’s first election for mayor in a century. Chirac held that position until 1995, when he was replaced by another RPR mayor, Jean Tiberi. Bertrand Delanoë, a member of the center-left socialist party (PS), won the office in 2001 and was replaced by another PS member, Anne Hidalgo, in 2014. These mayors were respectively associated with RPR control of the council from 1977 to 2001 and PS control of the council from 2001 onward. Changes since the creation of the French $5^{\text {th }}$ Republic in 1958 are reflected in Table 1 . The SEMs provided these local leaders control over development as they can direct decisions related to design and programming; this is quite different from what is typical in U.S. cities, where political involvement is largely indirect, primarily concerned with regulatory strategies such as zoning or tax incentives to influence private developers.

Table 1: Control of the local government in the City of Paris under the French $5^{\text {th }}$ Republic

\begin{tabular}{|l|l|l|} 
Years & $\begin{array}{l}\text { Institutional control and primary } \\
\text { political officials }\end{array}$ & Political parties in power \\
\hline
\end{tabular}




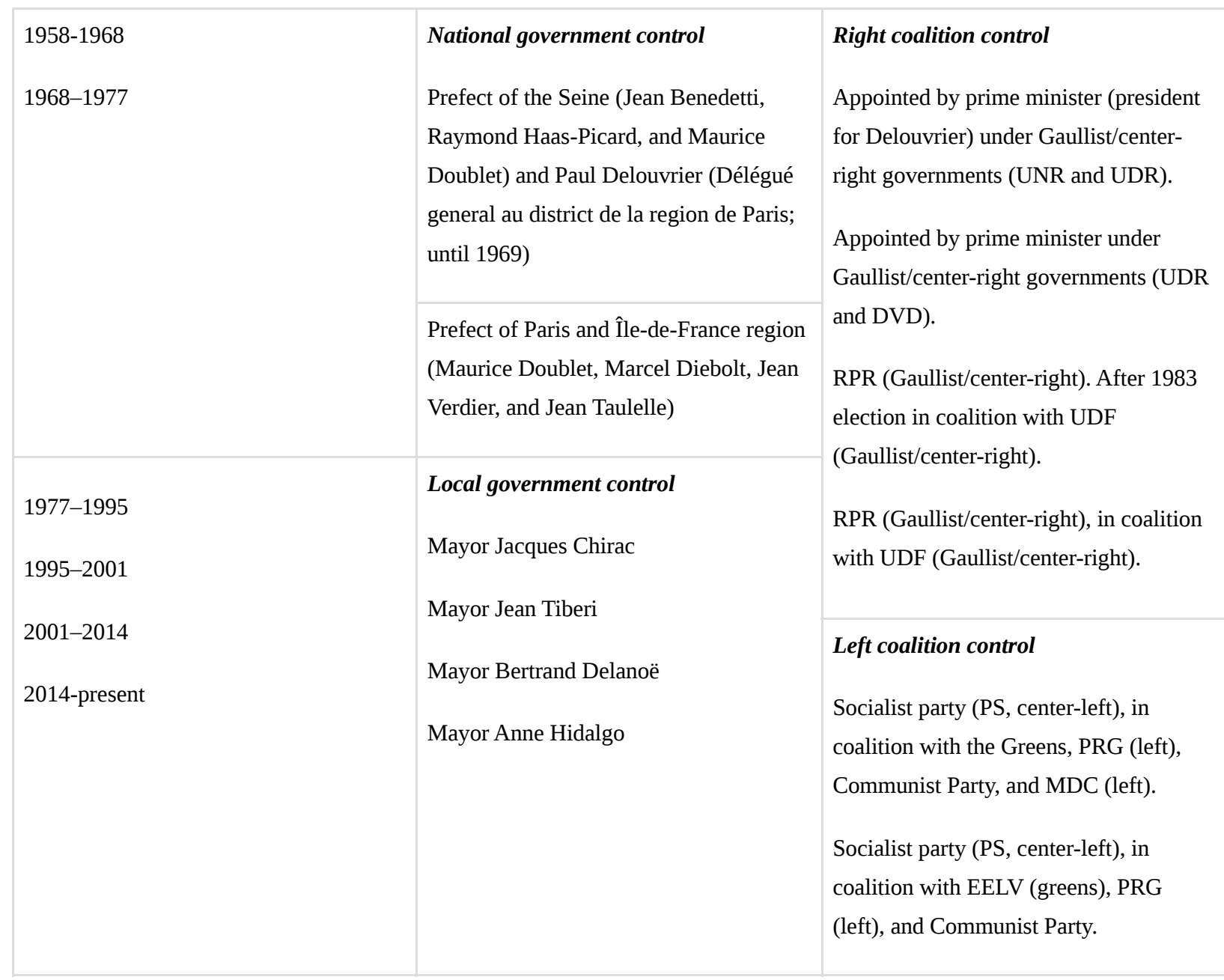

The cases are compared in Table 2 and mapped in Figure 1, which locates them along the Seine. I briefly summarize project characteristics before moving on to describe their collective evolution in programming and urban design.

Front-de-Seine (1) is a complex of 20 towers in the $15^{\text {th }}$ arrondissement on the city's southwest side, near the Eiffel Tower. Initial planning began in the 1950s, and the project came to fruition under the management of Paul Delouvrier, the national-government-appointed head of the Paris region during the 1960s (Alduy 1979). Delouvrier envisioned the project as a break from Paris' low-rise, high-density form exemplified by the $19^{\text {th }}$ century work under Georges-Eugène Haussmann. Rather, Front-de-Seine (and the five suburban new towns the national government was simultaneously constructing) represented “a radical disruption in lifestyle," as symbolized by its urban design of towers-on-platforms (known as dalles) that separate pedestrians from the street (Ozdoba 2013, 27). The project included retail, residential, and office space, and was mostly completed in the 1970s.

Bercy-Rapée (2) is an office complex completed during the same period as Front-de-Seine and under similar national-government auspices. The project is located on the city's southwest side, just adjacent to the Gare de 
Lyon, a major railway station. The project was envisioned as a new business district, eventually including office towers, hotels, and ground-floor retail space, constructed as mega-blocks, again on a dalle (APUR 1987). After the area was built, the national Ministry of Finance was implanted on a parcel to the south.

Citroën-Cévennes (3) was constructed on the former site of an automobile factory. Unlike the previous projects, it was implemented primarily by the city government since it was developed after Chirac became mayor in 1977 and after the gradual decentralization of national powers to local governments that accelerated during the administration of President François Mitterand. The project includes a large park along the Seine, housing, a hospital, and limited office space (APUR 1980). Its architectural style replicates the surrounding Haussmannian blocks.

Bercy and the adjacent ZAC Corbineau-Lachambeaudie (4) extend along the right bank of the Seine, southeast of the Ministry of Finance. They were built on land previously occupied by wine merchants and distribution warehouses, and they incorporate a multipurpose arena, a large park, residential areas, a low-scale commercial shopping center built in renovated wine facilities (Bercy Village), and offices. They are separated from the rest of the $12^{\text {th }}$ arrondissement by railways extending from the Gare de Lyon, and separated from the suburb of Charenton by railways and the city's ring road, the périphérique. They were mostly completed in the late 1980s to early 1990 s.

Paris Rive Gauche (5), the city's largest urban development project to date, occupies $2.5 \mathrm{~km}$ of waterfront and extends from the Gare d'Austerlitz station to the suburban city of Ivry. In the early 1980s, the area was considered to host parts of the 1989 Universal Exposition and 1992 Olympics, but neither event occurred. The project is partly built on land previously used for railways and logistics and also includes the almost-complete decking-over of an active railway (APUR 1990). This deck will offer a continuous link between the river and the rest of the $13^{\text {th }}$ arrondissement (Ernek 2014). The project includes the national library (BnF), thousands of apartments, a university, and office space that lines the large street at the project's center, Avenue de France. Other than the tall BnF, the project is built at seven to ten stories, with the exception of several towers planned for the border with Ivry.

Table 2: Major postwar mixed-use development projects in Paris along the Seine

\begin{tabular}{|l|l|l|l|l|l|}
\hline Project (ZAC) & (1) Front-de-Seine & (2) Bercy-Rapée & $\begin{array}{l}\text { (3) Citroën- } \\
\text { Cévennes }\end{array}$ & $\begin{array}{l}\text { (4) Bercy / } \\
\text { Corbineau- } \\
\text { Lachambeaudie }\end{array}$ & $\begin{array}{l}\text { (5) Paris Rive } \\
\text { Gauche }\end{array}$ \\
\hline Location & $\begin{array}{l}\text { Left bank, } 15^{\text {th }} \\
\text { arrondissement }\end{array}$ & $\begin{array}{l}\text { Right bank, } 12^{\text {th }} \\
\text { arrondissement }\end{array}$ & $\begin{array}{l}\text { Left bank, } 15^{\text {th }} \\
\text { arrondissement }\end{array}$ & $\begin{array}{l}\text { Right bank, } 12^{\text {th }} \\
\text { arrondissement }\end{array}$ & $\begin{array}{l}\text { Left bank, } 13^{\text {th }} \\
\text { arrondissement }\end{array}$ \\
\hline
\end{tabular}




\begin{tabular}{|c|c|c|c|c|c|}
\hline $\begin{array}{l}\text { Development } \\
\text { period }\end{array}$ & $\begin{array}{l}\text { 1970-1990 (all but } \\
\text { one tower } \\
\text { completed in } \\
\text { 1970s; commercial } \\
\text { center in 1978) } \\
\text { (APUR 2018). }\end{array}$ & $\begin{array}{l}\text { 1970-1978 } \\
\text { (adjacent Ministry } \\
\text { of Finance } \\
\text { completed 1989) } \\
\text { (APUR 2018). }\end{array}$ & $\begin{array}{l}\text { 1982-1999 (park } \\
\text { opened 1992; } \\
\text { hospital opened } \\
\text { 1999) (APUR } \\
\text { 1993; 2018). }\end{array}$ & $\begin{array}{l}\text { 1988-1997 (Arena } \\
\text { opened 1983; park } \\
\text { opened 1993; one } \\
\text { additional building } \\
\text { completed 2006) } \\
\text { (APUR 1993; } \\
\text { 2018). }\end{array}$ & $\begin{array}{l}\text { 1995-present } \\
\text { (national library in } \\
\text { 1995; most } \\
\text { construction began } \\
\text { in 2000s) (APUR } \\
\text { 2018). }\end{array}$ \\
\hline Land area & $\begin{array}{l}24 \text { ha* (APUR } \\
\text { 2018). }\end{array}$ & $\begin{array}{l}16 \text { ha* (APUR } \\
\text { 2018). }\end{array}$ & $\begin{array}{l}42 \text { ha (APUR } \\
\text { 1982) }\end{array}$ & $\begin{array}{l}51 \text { ha (APUR } \\
\text { 1987). }\end{array}$ & $\begin{array}{l}130 \text { ha (APUR } \\
1990) .\end{array}$ \\
\hline Program & $\begin{array}{l}\text { 3,179 housing } \\
\text { units; 132,000 m² } \\
\text { offices; two hotels; } \\
\text { commercial center } \\
\text { (SemPariSeine } \\
\text { 2018). }\end{array}$ & $\begin{array}{l}220,000 \mathrm{~m}^{2} \text { offices } \\
\text { (APUR 1987). }\end{array}$ & $\begin{array}{l}\text { 2,500 housing } \\
\text { units; 30,000 } \mathrm{m}^{2} \\
\text { industrial/ artisanal } \\
\text { uses; 7,000 } \mathrm{m}^{2} \\
\text { retail; } 67,000 \mathrm{~m}^{2} \\
\text { offices; } 14 \text { ha park } \\
\text { (APUR 1982) }\end{array}$ & $\begin{array}{l}\text { 2,200 housing } \\
\text { units; hotel; arena; } \\
25,000 \mathrm{~m}^{2} \\
\text { commercial center; } \\
\text { 120,000 m² } \\
\text { offices; } 12 \text { ha park } \\
\text { (APUR } 1987 \text {; } \\
\text { 2000). }\end{array}$ & $\begin{array}{l}\text { 7,500 housing } \\
\text { units; 745,000 m² } \\
\text { offices; 405,000 } \\
\text { m² commercial; }^{2} \text { 250,000 m² } \\
\text { library; 210,000 } \\
\text { m² university; }^{2} \text { 55,000 m² other } \\
\text { uses; } 10 \text { ha parks } \\
\text { (SEMAPA 2018). }\end{array}$ \\
\hline $\begin{array}{l}\text { Share social } \\
\text { housing }\end{array}$ & $\begin{array}{l}\text { 21\%* } \\
\text { (SemPariSeine } \\
\text { 2018). }\end{array}$ & & $\begin{array}{l}\text { 54\% (APUR } \\
\text { 1982). }\end{array}$ & $\begin{array}{l}50 \% \text {. Additional } \\
16 \% \text { intermediate } \\
\text { below-market } \\
\text { housing (APUR } \\
\text { 1987).** }\end{array}$ & $\begin{array}{l}\text { 50\% (SEMAPA } \\
\text { 2018). }\end{array}$ \\
\hline $\begin{array}{l}\text { Major public } \\
\text { attractions }\end{array}$ & $\begin{array}{l}\text { Beaugrenelle } \\
\text { shopping mall }\end{array}$ & $\begin{array}{l}\text { Ministry of } \\
\text { Finance (adjacent) }\end{array}$ & $\begin{array}{l}\text { Citroën Park, } \\
\text { hospital }\end{array}$ & $\begin{array}{l}\text { Omnisports arena, } \\
\text { Bercy Park, Bercy } \\
\text { Village shopping }\end{array}$ & $\begin{array}{l}\text { National library } \\
\text { (BnF), University }\end{array}$ \\
\hline
\end{tabular}




\begin{tabular}{|c|c|c|c|c|c|}
\hline Urban design & $\begin{array}{l}20 \text { modernist } \\
\text { towers projecting } \\
\text { from a superblock } \\
\text { platform with park } \\
\text { on top. Multistory } \\
\text { base with } \\
\text { commercial uses. } \\
\text { Pedestrians } \\
\text { discouraged from } \\
\text { using the street } \\
\text { with pedestrian } \\
\text { bridges and few } \\
\text { ground-floor retail } \\
\text { uses (before } \\
\text { renovation). }\end{array}$ & $\begin{array}{l}\text { Modernist mid-rise } \\
\text { glass towers } \\
\text { projecting from } \\
\text { multistory base. } \\
\text { Pedestrians can use } \\
\text { system of } \\
\text { skybridges and } \\
\text { balconies to move } \\
\text { between buildings. } \\
\text { Some ground-floor } \\
\text { retail uses. }\end{array}$ & $\begin{array}{l}\text { Haussmannian- } \\
\text { scale glass and } \\
\text { masonry buildings } \\
\text { surrounding park. } \\
\text { Ground-floor } \\
\text { circulation is } \\
\text { emphasized, with } \\
\text { several pedestrian- } \\
\text { only passages } \\
\text { between buildings. }\end{array}$ & $\begin{array}{l}\text { Center of project } \\
\text { largely composed } \\
\text { of Haussmannian- } \\
\text { scale buildings } \\
\text { with courtyards } \\
\text { surrounding major } \\
\text { park. Some have } \\
\text { streetfront retail } \\
\text { uses. Southern } \\
\text { portion of project } \\
\text { includes shopping } \\
\text { mall and museum } \\
\text { in low-scale } \\
\text { historic buildings, } \\
\text { and modernist } \\
\text { mid-rise office } \\
\text { buildings. }\end{array}$ & $\begin{array}{l}\text { With the exception } \\
\text { of large national } \\
\text { library, project } \\
\text { composed of } \\
\text { seven-to-ten story, } \\
\text { relatively large- } \\
\text { block glass and } \\
\text { masonry buildings } \\
\text { with courtyards } \\
\text { and streetfront } \\
\text { retail uses, } \\
\text { interspersed by } \\
\text { small parks. Major } \\
\text { avenue serves as } \\
\text { primary vehicular } \\
\text { axis. }\end{array}$ \\
\hline $\begin{array}{l}\text { Relationship to } \\
\text { the Seine }\end{array}$ & $\begin{array}{l}\text { Few active } \\
\text { commercial uses } \\
\text { facing riverfront in } \\
\text { buildings. Several } \\
\text { building entrances } \\
\text { pulled back from } \\
\text { riverfront. Arterial } \\
\text { roadway and } \\
\text { railway separate } \\
\text { the project from } \\
\text { the riverfront itself. } \\
\text { Connections to } \\
\text { waterfront } \\
\text { available only } \\
\text { about every } 500 \\
\text { feet. }\end{array}$ & $\begin{array}{l}\text { Expressway } \\
\text { separates project } \\
\text { from river. No } \\
\text { retail uses (save } \\
\text { gas station and } \\
\text { garage) fronting } \\
\text { river in buildings. } \\
\text { Riverfront } \\
\text { activated with } \\
\text { publicly accessible } \\
\text { boats, but no effort } \\
\text { to link the project } \\
\text { to the river, except } \\
\text { on de-Gaulle } \\
\text { bridge built in } \\
\text { 1996. }\end{array}$ & $\begin{array}{l}\text { Park extends } \\
\text { directly, without } \\
\text { grade change, to } \\
\text { riverfront thanks to } \\
\text { submerged } \\
\text { expressway and } \\
\text { the placement of } \\
\text { railway onto } \\
\text { viaduct. Buildings } \\
\text { pulled back from } \\
\text { riverfront, with no } \\
\text { active commercial } \\
\text { uses facing the } \\
\text { river. }\end{array}$ & $\begin{array}{l}\text { Expressway } \\
\text { separates project } \\
\text { from river. Most } \\
\text { buildings far from } \\
\text { riverfront, but } \\
\text { those close to } \\
\text { Seine (on south } \\
\text { side) have no } \\
\text { relationship to it. } \\
\text { Park has a tall } \\
\text { embankment wall } \\
\text { blocking river } \\
\text { views. Riverfront } \\
\text { is partly activated } \\
\text { with publicly } \\
\text { accessible boats, } \\
\text { but pedestrian } \\
\text { access (including } \\
\text { bridge) is available } \\
\text { only about every } \\
1,000 \text { feet. }\end{array}$ & $\begin{array}{l}\text { Active commercial } \\
\text { uses facing river in } \\
\text { buildings, with the } \\
\text { exception of along } \\
\text { the national library, } \\
\text { where a large } \\
\text { staircase extends to } \\
\text { street level. } \\
\text { Buildings front the } \\
\text { river, with a low- } \\
\text { speed arterial } \\
\text { featuring many } \\
\text { pedestrian } \\
\text { crossings along the } \\
\text { upper } \\
\text { embankment. } \\
\text { Riverfront } \\
\text { activated with } \\
\text { publicly accessible } \\
\text { boats. }\end{array}$ \\
\hline
\end{tabular}




\begin{tabular}{|c|c|c|c|c|c|}
\hline $\begin{array}{l}\text { Relationship to } \\
\text { surrounding } \\
\text { neighborhoods }\end{array}$ & $\begin{array}{l}\text { Project at a much } \\
\text { higher scale than } \\
\text { surroundings. } \\
\text { Street grid of } \\
\text { surrounding } 15^{\text {th }} \\
\text { arrondissement } \\
\text { eliminated. Little } \\
\text { effort at creating } \\
\text { walkable } \\
\text { continuity between } \\
\text { project and } \\
\text { surrounding areas. }\end{array}$ & $\begin{array}{l}\text { Project separated } \\
\text { by major, } \\
\text { pedestrian-hostile } \\
\text { roads on all sides. } \\
\text { Towers at a much } \\
\text { larger scale than } \\
\text { surroundings. } \\
\text { Much larger street } \\
\text { grid than } \\
\text { surrounding areas. }\end{array}$ & $\begin{array}{l}\text { Project largely } \\
\text { continues the street } \\
\text { grid of surrounding } \\
15^{\text {th }} \\
\text { arrondissement. } \\
\text { No clear } \\
\text { discontinuity in } \\
\text { scale or street } \\
\text { design between } \\
\text { project area and } \\
\text { surroundings. }\end{array}$ & $\begin{array}{l}\text { Mostly cut off } \\
\text { from remainder of } \\
12^{\text {th }} \\
\text { arrondissement by } \\
\text { railway. One } \\
\text { pedestrian link is a } \\
500 \text {-foot, dark, } \\
\text { inhospitable tunnel } \\
\text { under tracks. } \\
\text { Similar street grid } \\
\text { to surroundings. }\end{array}$ & $\begin{array}{l}\text { Virtually complete } \\
\text { bridging over } \\
\text { tracks planned, } \\
\text { connecting to } 13^{\text {th }} \\
\text { arrondissement in } \\
\text { many locations. } \\
\text { Future projects } \\
\text { include retail street } \\
\text { under highway to } \\
\text { connect with } \\
\text { suburb of Ivry. } \\
\text { Similar street grid } \\
\text { and scale as } \\
\text { surroundings, with } \\
\text { exception of } \\
\text { towers planned for } \\
\text { project's southern } \\
\text { edge. }\end{array}$ \\
\hline
\end{tabular}

Figure 1: Location of case-study projects within the city of Paris, and site plans of each project. Source: The author, using data from APUR 2018.

\section{Evaluating project programming and urban design}

What were the approaches to project programming and urban design in each of the five cases, and how did they change over time? To answer this, I delve into archival documents and official statements to identify 12 development logics, which I define as planning goals that affect project plans and outcomes, and which are reflective of trends across multiple investments. This novel categorization exposes multiple decision-making motivations. These logics overlap—more than one is at play simultaneously—and are sometimes contradictory; for example, an emphasis on providing social housing limits space in a project for commercial or tourist-oriented uses. I endeavor to show when logics become more or less important, as reflected in programming and design.

Figure 2 offers graphical documentation of these logics. It shows their overlapping nature, indicating the time periods in which each played a dominant role in defining project programs and designs. Logics that are primary 
during a specific period are indicated with a solid representation; when they are secondary (declining or increasing in importance), they are dashed. For example, the logic of reducing space for cars (I) was increasing in importance but not yet fully part of the city's design focus from the mid-1990s to the early 2000s, when it became a primary goal.

Several of the logics, which I detail below, relate to programming, which, in turn, can be interpreted by the reader as having an orientation towards boosting the market or expanding social needs, but typically represent a broader array of local goals. Contrary to much of the literature suggesting that development projects encourage inequality, Paris has devoted increasing effort to affordable housing throughout the period studied (A). Planners' emphasis on economic growth through the creation of tertiary-sector spaces (B) and enticing investment through major attractions (C) both pre-dated the period understood as corresponding to the neoliberal turn, and declined in importance after the left took control of the city council in 2001. The devolution of power from the national to local government, beginning in 1977, encouraged a brief foray into focusing on industrial uses (D) and a longer-term effort to expand local housing supply (E).

Other logics are related to urban design. The national government focused on towers-on-platforms $(\mathrm{F})$ and using the river as only an aesthetic device to be looked at (J), both reflecting an interest in isolation from surroundings. The rise of local control, on the other hand, reaffirmed the existing street grid $(\mathrm{H})$ and an extension of parks to the river (K). These changes also occurred in connection with the devolution of power from the national to local government. Meanwhile, left-wing control of the council brought an end to the focus on automobile circulation (G), and its replacement with a reduction in space for cars (I). This change allowed the river to become an extension of the neighborhood (L).

Fig. 2: Shifts and continuities in approaches to urbanism, seen through 12 development logics. Prepared by the author.

\section{The role of development projects: A programmatic perspective}

In evaluating project programming, I identify five distinct logics used to justify and ultimately determine what uses are included. First, in opposition to frequent claims, projects concentrate heavily on the provision of subsidized housing for low-income families, a manifestation of a concern for social equity (Figure 2: A). This focus, moreover, has expanded since the 1960s, not retreated in the face of a need to attract investment. It has been supported by political leaders on both the left and right, and been reinforced despite the broader economic changes accompanying the neoliberal turn. Public documents show a continued interest in avoiding embourgeoisement — gentrification — and the homogenization of districts by class that was occurring in neighborhoods outside of public projects (APUR 1970). For Front-de-Seine, the national government "conduct[ed] a rigorous social-housing policy in contrast to the general Parisian [private-sector] trend" 
(Godard 1973, 15; Robert 1995). Institutional change had a key impact: Once local officials gained power after the 1977 election, they reinforced this commitment to social housing, making it a major element of the city's first self-made plan (APUR 1982).

French planners manifestly had few concerns about adding low-income units to visible, even touristic sites. For example, they lined the plaza in front of the Centre Pompidou art museum, built in the 1970s, with affordable housing — not hotels or apartments for higher-income families (APUR 1980). Similarly, they planned for social housing along the park at Citroën and adjacent to the BnF at Paris Rive Gauche. As Table 2 indicates, each of the four projects with housing includes a significant share-about 50 percent among the three most recent projects, up from 21 percent at Front-de-Seine-devoted to social housing. Political officials believed there was coherence between waterfront development on special sites and serving the residential needs of the poor. On this subject, ideological change was also important. This priority has been reinforced by the left alliance in power since 2001 (Clerval and Fleury 2009); the latest riverside development project, Bercy-Charenton (indicated in Figure 1; it has not yet begun construction), will include 57 percent social housing units and an additional 20 percent will be “intermediate” subsidized middle-class housing (APUR 2008).

Simply constructing new social housing, however, does not necessarily mean serving the poorest of the poor. In the 1960s and 1970s (such as at Front-de-Seine), planners used new construction to replace existing housing, in some cases actually reducing the total number of residences (Godard 1973). Just as importantly, subsidized housing was sometimes more expensive to rent than the previous, degraded private-market apartments (Clerval and Fleury 2009). For sites with only industrial uses before, though, new developments did increase the housing stock.

The priority placed on affordable housing by successive governments coexisted with planners' use of such projects to promote economic growth, the second development logic (B). In accordance with Swyngedouw et al. (2002), the "need" to compete internationally played a major role in project programming. In the context of declining in-city population, Paris' reduced importance in the regional economy, and rapid industrial decline, national planners in the 1960s and 1970s focused on creating tertiary-sector complexes-made most apparent in the Bercy-Rapée project, which did not include housing at all. These districts would meet the perceived demand for large floorplates to be filled with offices (APUR 1970). Rather than distribute such employment throughout existing districts, planners emphasized office-job concentration in key areas (APUR 1974a). One report noted "the affirmation of the tertiary sector is an essential element of the maintenance of Paris' dynamism” (APUR 1980: 76). In so doing, while development projects were not necessarily gentrifying out residents, they replaced places for working-class jobs with environments for white-collar ones.

National planners chose the south (at Montparnasse) and the southeast (around the Gare de Lyon and Gare

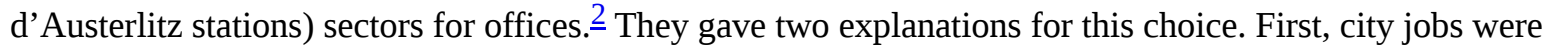
"unbalanced" to the west-a worsening problem because of the growth of the suburban La Défense cluster and the earlier decision to build Front-de-Seine. This produced long commuting times for people in the east (APUR 
1970). The southeast was well linked to the transportation network, with its two railway stations and the riverfront highway built in the 1960s (APUR 1971). Thus, the national government's vision for Bercy-Rapée included enormous quantities of office space (Godard 1973), and planners slated parts of the areas eventually developed as Bercy and Paris Rive Gauche as major tertiary zones, specifically designed for corporate headquarters (Bauer 1992).

During this period, public documents clearly prioritized an orientation toward reinforcing the market in order to compete. State-level actors presented developments as essential "to permit Paris to continue to fulfill its great role as capital and important international city” (APUR 1971, 14). These projects had national portent; one project "is not only an indispensable service to the city... it's a service provided to the nation," a report noted (APUR 1974b, 9). Mayor Chirac, too, wrote that Paris Rive Gauche "extends beyond the Parisian frame... [what mattered was] the role it would play in the Europe and world of the future” (APUR 1990, 5). Planners emphasized that developments made the city competitive; they were physical manifestations of its international standing (APUR 1990, 10-12; Le Journal de Seine Rive Gauche 1991).

This vision, however, changed when first, local inhabitants and artist groups staged protests in the 1990s related to Paris Rive Gauche that contested the view that economic growth should be a primary goal, and, second, the 2001 municipal election brought the left coalition, which had supported the protestors, to power (Freemark 2010). Though commodification of public spaces increased through the addition of riverside bars and restaurants, planners reduced focus on economic growth targeting perceptions of investor needs. A 1970 APUR report $(1970,6)$ noted "the necessity of maintaining in France a pole of attractivity for the headquarters of major multinational companies... and which need to be located next to one another.” Under the altered 2002 project plan for Paris Rive Gauche, on the other hand, the city reduced offices from 900,000 $\mathrm{m}^{2}$ to 745,000 m2, and expanded space for housing, local amenities (such as schools and arts), and parks (Nez 2012). Project plans for Bercy-Charenton include office space, but the city does not frame these as efforts to build economic competitiveness. Rather, the project's goal is "envisioning putting into place shared, innovative solutions in terms of housing, work, energy, and the fight against climate change” (Mairie de Paris 2018, 2). Social needs are increasingly being prioritized over the market from this perspective.

Intimately related to economic development goals is planners' use of projects as locations for attractions, the third logic I identify (C). Paris has a long history of implanting touristic sites along the Seine: the parade of architecturally significant monuments from the Eiffel Tower to the Louvre is a key element of the city's identity (APUR 2011). Presidents Mitterand and Chirac (he moved up from the mayoralty in 1995) reinforced this link in the 1980s and 1990s through riverside grands projets such as the Institut du Monde Arabe and the Musée du Quai Branly. These flagships, Vila Vázquez (2011) argues, catalyze urban regeneration and attract new investment in themselves.

Both when the city was under national and local control, planners designed projects to bring in crowds. Initial plans for Bercy included a "cultural amenity” (APUR 1971), eventually coming into being as the arena 
completed in 1983, before the rest of the project. When President Mitterand announced plans for the BnF, thenMayor Chirac offered a portion of Paris Rive Gauche, before development had commenced (APUR 1990). $\underline{3}$ Planners designated Bercy for popular consumption, integrating a shopping center for the "grand public" interested in "the great French tradition of wine and the table" (APUR 1987, 116). These development zones, then, allowed planners to implant attractions that extended beyond resident needs, and those attractions were used as catalyzers for other project sections, and perhaps ultimately attracted private investment. Yet the tradition of using the waterfront as a site for the city's biggest attractions declined after the 2001 political transition; left-wing city leaders have located major new tourist-related investments on the border between city and suburbs, not on the river. 4

But the waterfront development projects did more than simply respond to a need for housing, office space, and tourist attractions. After the 1977 devolution, the city council adopted a fourth development logic, a view that industry should be supported (D). This approach can be seen as pursuing both market and social objectives; it was meant to increase the city's economy while ensuring continued jobs for low-skilled workers, respectively. Faced with a transitioning economy where manufacturing and industrial uses were perceived as less relevant, the national government had at Front-de-Seine and Bercy-Rapée (and in early plans for Bercy and Paris Rive Gauche) articulated little effort to retain or support industry. Yet, once in power, local decisionmakers pursued a different course. The 1977 plan, the city's first self-produced effort, committed to industry, proposing a modern port at Paris Rive Gauche and incorporating space for artisanal and industrial uses at Bercy and Citroën (APUR 1980; 1982). At Paris Rive Gauche, planners recommended building a large new building to meet industrial needs (APUR 1987).

Yet the city's interest in industry declined in the 1990s as Paris continued losing employment outside of the tertiary sector. Local planners came to see the modern port as unviable and thus abandoned it (APUR 1987). Moreover, faced with limited success, the city transformed spaces designed for the use of food distributors and manufacturers at Bercy into the retail shopping area described above, and an exposition building for their use was converted to offices in 1993 (Nelson 2001).

Decentralization in 1977 also brought with it the city focusing on supporting community needs, the fifth development logic (E). Alduy $(1979,187)$ notes that "from an offensive effort, tied to an economic program, [the city] moved toward a defensive attitude founded on safeguarding the successes of the previous period;” this change in posture had real impacts on what types of activities projects included. As city population losses mounted (APUR 1980), housing and local population growth became more concerning for local politicians. This interest was opposed to the national government's previous proposals for sprawling regional population growth. For the city's redevelopment director Alain Grellety Bosviel, at Bercy, "it’s not the creation of a new town that mobilizes us, but the goal of building a new district for Paris” (APUR 1993, 159). Paris' localized effort paralleled the decision to stop bulldozing existing communities- the norm in the city's earlier, nationalized urban renewal—and instead to expand housing availability. Because both the Bercy and Paris 
Rive Gauche projects were built on previously uninhabited sites, their construction eliminated no existing housing and added thousands of units, thus relieving concerns about population loss noted above.

Thus planners replaced the world-headquarters sites of past proposals with plans to augment lives of people in the existing city by adding living space and giving the people who lived there environments designed for their needs. The post-1977 city plans halved planned office space in the unbuilt portions of Bercy-Rapée (APUR 1987). The city reimagined the goals of its new attractions; elements like the park at Bercy—once imagined by national planners as a sort of French Tivoli Gardens-were now envisioned by local planners as "closer to the quotidian than the spectacular" (APUR 1987, 114). At Citroën, plans articulated that the "principal function" of the park would be "a large facility whose purpose is to prioritize the local” (APUR 1993, 90).

From a programming perspective, then, these developments counter several expectations that might be derived from the scholarship. There is no convergence in Paris toward inequality-increasing, investment-driven approaches following a neoliberal turn; if anything, the opposite is true. Moreover, transitions in institutions (the 1977 decentralization reform) and in ruling ideology (the 2001 council win by the left) suggest opportunities for varying prioritization of development logics. I identify similar alternative approaches with respect to urban design in the next section.

\section{Transformations in urban design}

The postwar period was associated with a dramatic rethinking of how urban space should be designed in Western cities. As Fishman (2011) describes, the modernist movement's reigning paradigm of high-rise, open landscapes, commonly prescribed for urban redevelopments until the early 1970s, was replaced by the neotraditional goal of spatial enclosure. This swing occurred in Paris, too, and not in a way that created isolated, exclusive spaces, as many scholars suggest is the case for major projects. Using the APUR archives, I identified four logics of urban design that dominated public decision-making over time, summarized in Figure 2 above. These design logics were promoted simultaneously as the aforementioned programming logics, and do not connect as well to broader pro-market or pro-social orientations as those others. Yet the use of design logics, again available to decisionmakers throughout the process, but prioritized in different ways, was another essential attribute that determined how riverfront projects work. Figure 3 illustrates differences between the projects through photographs.

Fig. 3: Comparison of urban design elements among the five case-study projects. Prepared by the author.

National planners used the design logic of dalles (platforms; Figure 2: F), a popular feature of French urbanism in the 1950s through 1970s, to physically separate different modes of transportation at Front-de-Seine and Bercy-Rapée. Plans kept cars to the ground level, where they connect to tunnels and parking garages (Figure 3: 
1-1). Pedestrians move about one or two levels above, on a mega-block platform that links tower bases. In mixed-use complexes, the primary entrances are on the platform level, where there are sometimes retail stores. For both complexes, the dalle was combined with modernist, rectilinear architecture and tall buildings, much higher than the surrounding community. The mega-block form produced by this type of urbanism was radically different than the Haussmannian structure of small blocks and courtyards that dominates Paris.

Local planners argued by the 1980s that the result was a complete "rupture... in relationship to the surrounding district which had been totally 'erased' without a coherent urban composition replacing it” (APUR 1982, 10). $\underline{5}$ Henri Bresler and Isabelle Genyk comment, "since its construction, Front-de-Seine appeared like an aircraft carrier moored to the quay, an object pasted down rather than connected to its surroundings” (APUR 2010, 115). This profound isolation reflected that the projects were conforming to the image of such developments frequently offered by scholars, meant to be isolated showpieces, apart from the problems of the surrounding community, meeting the goal of investor attraction that their programs implied.

Connected to this physical isolation was an interest until the 1990s among both national and local planners in supporting automobile movement, the second design logic (G). The national government completed the rightbank Seine expressway in the 1960s, and began making plans for a similar left-bank scheme in the early 1970s (APUR 1971; 1973). Planners assumed that future travel would have to be eased for motorists-people needed to get to work if Paris was going to continue attracting jobs.

Even the post-1970s projects that moved away from the dalle sought to speed car travel through their blocks. At Bercy, local designers made no effort to cull traffic along the Seine (APUR 1982). Rather, the development's waterside edge is cut off by a large embankment wall designed to mask noise (Figure 3: 4-4). Pedestrians were instructed to go over the high-speed road—not interrupt car movement. The project provides ample parking for business and touristic use (APUR 1987). At Paris Rive Gauche, initial plans included an underground expressway through the project—a solution undertaken at Citroën (APUR 1990).

If decentralization for increased local power in 1977 did not alter planners' interest in speeding car movement, it did lead to architecture that replicated Paris' historic form — the third design logic (H). Indeed, despite the expressways that border them, Bercy and Citroën departed significantly from the towering mega-blocks of Front-de-Seine and Bercy-Rapée in terms of their street grids and built forms. $\underline{6}$ The Chirac mayoralty argued that development should emphasize diverse uses, streets connected with their surroundings, small blocks, and clearly defined public spaces (APUR 1982). This initiative was to some degree an answer to the negative public reaction to the towers built in the 1970s at Montparnasse and around the Place d'Italie. At Citroën, the environment is thus hard to differentiate from the nearby community; there is no isolation. This is less the case at Bercy; though its appearance was Haussmannian, the city made little effort to link it to the rest of the $12^{\text {th }}$ arrondissement by spanning the tracks. 
But at Paris Rive Gauche, the city has successfully executed an effort to use developments to link between existing neighborhoods. For Thérèse Cornil, who headed the SEM that led its development (SEMAPA), the district was "conceived not as a rupture with Parisian urbanism, but more as a continuity between different spaces that previously were indifferent to one another [qui s'ignorent]: the two banks of the Seine, the $5^{\text {th }}$ and $13^{\text {th }}$ arrondissements" (Les Cahiers M2 1994). Unlike at Bercy, the city adopted for the first time a plan to span the tracks emanating from the Gare d'Austerlitz to link neighboring districts with the new zone and the Seine (APUR 1990). Paris Rive Gauche will ultimately include little evidence of any barrier (other than topographical) between "old” Paris, this new district, and the river. Planners made this approach even more explicit through the transformation of several previously existing industrial buildings into university spaces. Not only would the area look like Paris, but it would be part of Paris. ${ }^{7}$ Here, too, urban design is a reflection of programmatic choice: A prioritization, built into the streets, of the existing and local over the isolated attraction.

In the most recent riverfront projects, however, planners have ceased their focus on replicating the Parisian built form, suggesting a diminishing commitment to this logic. The last-to-be-completed portions of Paris Rive Gauche and current plans for Bercy-Charenton include tall towers (Mairie de Paris 2018). For Mayor Hidalgo, the goal of bringing tall buildings back to the city dated to the beginning of her stint as deputy mayor with the left's municipal takeover in 2001 (Bonnefille 2017). The council has endorsed the view of towers as useful mechanisms to densify the city and connect it with its suburbs. This change has taken years to be executed, in part because of significant opposition from right-wing councilors and some in the green movement. At least now, however, dramatic physical change along the Paris waterfront is associated with a left-wing viewpoint.

The local left coalition also reduced the prominence of automobiles in projects' designs, the fourth design logic (I; Halpern and Le Galès 2016). Rather than "being happy enough with the aesthetic view of the Seine from the towers," as had been the case at Front-de-Seine and Bercy-Rapée, city policy now stated that the riverfront was to become a multimodal space with a seamless pedestrian passage between projects and the water (APUR 2007, 22). After halting efforts to expand pedestrian, bike, and transit options by Mayor Tiberi but little substantial progress, Mayor Delanoë, backed by his socialist and green council majority, converted parts of the Seine expressway to a summer-only beach called Paris Plages beginning in 2002, allowing "neighborhoods continuing up to the edge of the water" (APUR 2010, 86). His successor Hidalgo closed the expressways off entirely, despite cries from members of the right-wing opposition that she would be impeding movement and the city's economy. At Paris Rive Gauche, where initial plans included the riverfront expressway and a road built literally through the Gare d'Austerlitz station, plans adjusted to benefit pedestrians and bicyclists-local, slower movement was prioritized over the (wealthier) people moving more quickly in private cars (Nez 2012).

\section{Interactions with the waterfront}

The projects' riverfront sites play a special role in urban design worthy of independent analysis. These locales, I have noted, can be commandeered as spectacular sites that promote economic growth and tourism, or, by contrast, as ground for programming and connections responding to local needs. The importance of these sites 
is especially relevant in Paris, where monuments have long been located along the Seine and the central riverfront is designated a UNESCO World Heritage Site. Here, I chart the transition in thinking about the role that developments should play through three logics of waterfront connectivity, which can be understood as extensions of the urban design logics described above.

The waterfront logic that dominated Parisian planning from the 1950s through early 1970s (J) was that of buildings fronting the river, failing to interact with it. The national government saw it mostly as a convenient location for new highways (Desailly 2007) and did not consider transforming it into something like Baltimore's Harborplace. In the plan explaining why an office center should be constructed in the southeast sector, for example, no mention is made of the potential beauty offered by the riverfront site (APUR 1971). For leaders at that time, "the Seine [was] just... an obstacle" (APUR 2010, 31).

Yet the construction of the initial postwar riverfront projects raised two concerns among even national planners by the mid-1970s. One, they saw Front-de-Seine's buildings as positioned too close to the river, failing to adequately separate the natural and the manmade (APUR 1974a). Two, the fact that the buildings were constructed as mega-blocks at Bercy-Rapée meant the "impossibility of all 'opening' toward the Seine” from other neighborhoods (APUR 1974b, 56). There, retail uses nearest to the river currently include a gas station and a rental-car facility. The project's design and the riverfront uses that accompany it work together to reinforce a pedestrian-hostile environment (Figure 3: 2-3).

But local planning oversight, beginning in 1977, brought a shift in waterfront design. Planners pulled buildings back from the river, locating them behind large parks, the second waterfront logic (K). Citroën and Bercy, undertaken in the 1980s, embody this design approach. Because of their low heights, most component buildings do not even have a view of the river. And the shopping center at Bercy (Figure 3: 4-2), oriented toward outsiders, has no link to the Seine at all despite the fact that it is just a few meters away. The link between shopping centers and the natural environment of the waterfront—so obvious for planners in Baltimore —was nonexistent in Paris.

These projects’ parks did emphasize new connections, “open onto the Seine” (APUR 1993, 88). At Citroën, pedestrians would be able to walk directly, at grade, from the park to the riverfront (Figure 3: 3-4; APUR 1982), though they cannot do the same from the built elements of the development. And at Bercy, though the project was separated from the Seine by a high wall, an elevated terraced promenade was planned to link the

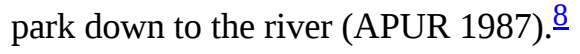

City planners altered their approach once again in the 1990s, shifting to a conception of riverfront space as a continuation of surrounding neighborhoods, the third waterfront logic ( $\mathrm{L}$ ). At Paris Rive Gauche, the riverside was no longer a utilitarian location for offices or the extension of parks. Mixed-use buildings were placed directly along the waterfront, not pulled back as at Bercy or Citroën, and streets run from the waterside quays into the surroundings (APUR 2010). Uniquely, then, it includes in-building retail shops facing the river-no 
such uses are located in the other projects. There has been riverfront commodification in some cases, such as through relatively pricey riverfront bars and restaurants placed within public space (Figure 3: 5-4), but this turn toward the river is not primarily about tourism. As of summer 2018, retailers lining the waterfront in the district include a hardware store specializing in tiles; a bakery; several mid-priced restaurants; a gardening store; and a bank. A floating public pool was added to the river just off the side of the project (APUR 2007), but this is no amusement park: Day passes cost just €3.60. The new district may be made up of new buildings, but it acts like the existing city in form and function. The development thus links the river almost seamlessly to older neighborhoods.

Paris' most recent development plans at Bercy-Charenton further the approaches piloted at Paris Rive Gauche (APUR 2008). For Mayor Delanoë, the Seine is "a unifying and fundamental element for the Paris region" (APUR 2010, 4). Local planners' primary goal for this site is not to create a new investment opportunity, but to encourage added cohesiveness between central city and suburb while furthering river access through new corridors over and under the infrastructure barriers that traverse the area (APUR 2007).

The urban design logics described here-including those related to the riverfront specifically-counter many of the expectations scholars have put forth about major developments. Importantly, I show that while planners used projects to isolate and exclude during the beginning of the postwar period, that approach has disappeared more recently. The institutional change that brought on local control in 1977 clearly resulted in thes altered priorities. Moreover, I have demonstrated multiple approaches to urban design depending on the ideologies of those in power. The right-wing's interest in replicating the design of Haussmannian Paris, for example, has been increasingly abandoned by left-wing leaders since they took power.

\section{Conclusion: A Parisian exception?}

This study examines how Paris approached the planning of postwar, waterfront developments. Through the identification of 12 development logics linked to project programming and design, I question the scope of the neoliberal turn in urban planning. I do this by emphasizing the continued importance of public intervention within specific institutional parameters, the plurality of possible logics, and the importance of political ideologies in defining local decision making.

The Paris example shows the failure of the description put forth by many scholars of major projects as primarily responding to neoliberal political economy by converging toward a focus on economic development, encouraging inequitable outcomes, and turning themselves inward. Rather, I find that projects emphasized needs of the wealthy and isolated design before the period ascribed to the neoliberal turn, and that recent decades have been associated with growing efforts to increase access to affordable housing $\underline{9}$ and to design connections with the existing city. These changes resulted from institutional modifications that brought power to the local council in 1977 and a new ruling local ideology beginning in 2001. 
It is worth emphasizing that, while some of these changes reflect broader changes in global thinking about how to undertake project programming and urban design, that transition is not adequate to explain what occurred in Paris. Several key pieces of evidence are worth noting. One, the fact that scholars have documented many recent urban developments elsewhere primarily focused on aims like privatization and commodification while Paris manifestly has taken a different tack suggests that general trends are not universal. Two, the sharp transition in approaches to project urban design that accompanied decentralization in 1977—specifically, a move away from tower-on-platform design — was sudden and thus difficult to explain other than by a shift from national to local power. And three, right-wing local leaders, in the minority since 2001, have contested left coalition-led moves such as pedestrianization of the Seine riverbank and new towers on the city's edgesuggesting there is no consensus even in Paris in line with global views about best practices.

The development logics I identify coexisted during much of the study period, but were prioritized by planners to different degrees over the study period. When they clashed with one another-such as reserving space for offices or social housing - people in power had to make decisions about which to preference, and the result was made manifest in approved plans. By highlighting their changing importance by successive planners and elected officials, I demonstrate that there is no single mode of urban project development; the sense that major projects must adhere to the norms of global competitivity can be discarded, leading to more equitable programming and more integrated urban design. Deterministic convergence-whether toward neoliberal goals, responding to the "pragmatic" needs of local residents, or anything else—is not occurring, but decision making is, rather, impacted by institutional and ideological agendas in a context where alternative choices are feasible.

It is unquestionably true that Paris overall has had a reduction in low-income residents over the time period examined, increasing inequality as a whole (Clerval 2013). The riverfronts themselves are hardly free of commodification; in many places they feature expensive restaurants monetarily off-limits to much of the population. Moreover, my analysis is limited. I consider the design-politics of one, unique city. As such, the argument I present should not be construed as representing conditions in other cities. By relying primarily on official reports and plans, I do not delve much into the concerns of opposition groups. Other methods could better assess project outcomes. Even so, this case study undermines the expectation that global cities such as Paris generally plan for isolated projects aimed at tourists and the wealthy.

Future research, using interviews and spatial statistics, should engage to identify the degree to which these development logics — present in plans—play out on the ground in implementation, and whether the alternative options demonstrated here are present elsewhere. Paris, as a uniquely attractive city, may have local officials with power that provides them broader ability to act. Thus understanding the degree to which institutional arrangements and ruling ideologies influenced outcomes is an important next step in identifying the generalizability of this case. 


\section{Acknowledgements}

I thank Daniel Nichanian, Kathleen Thelen, and Lawrence Vale for their comments on drafts of this paper. In addition, I appreciate the extremely helpful insight provided by the Projections editors and the anonymous reviewers during the revision process.

\section{References}

Notes: Quotes from texts originally in French were translated by the author. APUR is the Atelier parisien d'urbanisme.

Aldrich, Robert. 1982. “The Building of Manhattan-sur-Seine.” Review Essay. Journal of Urban History 9, no. 1 (November): 89-97.

Alduy, Jean-Paul. 1979. "L’aménagement de la région de Paris entre 1930 et 1975 : de la planification à la politique urbaine.” Sociologie du travail 21, no. 2: 167-200.

APUR. 1970. Paris Projet 2. Paris.

APUR. 1971. Paris Projet 5. Paris.

APUR. 1973. Paris Projet 9. Paris.

APUR. 1974. Paris Projet 10-11. Paris.

APUR. 1974. Paris Projet 12. Paris.

APUR. 1980. Paris Projet 19-20. Paris.

APUR. 1982. Paris Projet 21-22. Paris.

APUR. 1987. Paris Projet 27-28. Paris.

APUR. 1990. Paris Projet 29. Paris.

APUR. 1993. Paris Projet 30-31. Paris.

APUR. 2000. Berges de la Seine: Secteurs amont et aval de Paris. Paris.

APUR. 2007. Un nouveau regard pour le Site de la Seine: Accessibilité, attractivité, biodiversité. Paris.

APUR. 2008. Paris Sud-Est Bercy Charenton: Le Chaînon Manquant. Paris.

APUR. 2010. Paris, Métropole sur Seine, Paris Projet 40. Paris. 
APUR. 2011. Paris, rives de la Seine : Le projet des berges de Seine en 2012. Paris.

APUR. 2018. “Plateforme Open Data.” Accessed May 10, 2018. http://opendata.apur.org/.

Bauer, Anne. 1992. “L’opération Seine Rive Gauche boucle son plan financier.” Les Échos, March 13, 1992.

Bonnefille, Pascal. 2017. “Comment Anne Hidalgo transforme Paris.” L’Hémicycle, December 11, 2017.

Brenner, Neil. 2004. New State Spaces. Oxford: Oxford University Press.

Busquets, Joan, and Felipe Correa, eds. 2006. Cities: 10 Lines. Cambridge: Harvard University Graduate School of Design.

Chang, T.C., and Shirlena Huang. 2011. "Reclaiming the City: Waterfront Development in Singapore.” Urban Studies 48, no. 10 (August): 2085-2100.

Clerval, Anne. 2013. Paris sans le peuple. Paris: La Découverte.

Clerval, Anne, and Antoine Fleury. 2009. "Politiques urbaines et gentrification, une analyse critique à partir du cas de Paris.” L'Espace Politique 8, no. 2: 1-17.

Crouch, Colin, and Patrick Le Galès. 2012. “Cities as national champions?” Journal of European Public Policy 19, no. 3: 405-419.

Desailly, Bertrand. 2007. “Les metamorphoses des paysages fluvio-urbains en France.” Bulletin de la Société de Géographie de Toulouse 2007: 23-30.

Eidelman, Gabriel. 2016. "Rethinking public land ownership and urban development: A Canadian perspective.” Cities 55: 122-126.

Eidelman, Gabriel. 2018. "Failure When Fragmented: Public Land Ownership and Waterfront Redevelopment in Chicago, Vancouver, and Toronto.” Urban Affairs Review 54, no. 4: 697-731.

Ernek, Benoît. 2014. "Paris Rive Gauche Project: (Re)developing the City on the City.” LHI Journal 5, no. 3: 123-129.

Fishman, Robert. 2011. “The open and the enclosed: Shifting paradigms in modern urban design.” In Companion to Urban Design, edited by Tridib Banerjee and Anastasia Loukaitou-Sideris, 30-40. London: Routledge.

Freemark, Yonah. 2010. “Vive Rive Gauche.” Planning. February. 
Godard, Francis. 1973. La rénovation urbaine à Paris: Structure urbaine et logique de classe. Research and analysis by Manuel Castells, Henri Delayre, Catherine Dessane, Francis Godard, and Chantal O’Callaghan. Mouton: École Pratique des Hautes Études.

Gordon, David L.A. 1997. "Financing Urban Waterfront Redevelopment.” Journal of the American Planning Association 63, no. 2 (spring): 244-265.

Gospodini, Aspa. 2002. “European Cities in Competition and the New 'Uses' of Urban Design.” Journal of Urban Design 7, no. 1: 59-73.

Goss, Jon. 1996. "Disquiet on the waterfront: Reflections on nostalgia and utopia in the urban archetypes of festival marketplaces.” Urban Geography 17, no. 3: 221-247.

Halpern, Charlotte, and Patrick Le Galès. 2016. "Transformative Urban Transport and the Making of an Urban Regional Mode of Governance: The Case of Paris and the Ile-de-France Region.” In Transforming Urban Transport-The Role of Political Leadership, edited by Diane Davis and Lily Song. Cambridge: Harvard University Graduate School of Design.

Jauhiainen, Jussi S. 1995. "Waterfront redevelopment and urban policy: The case of Barcelona, Cardiff and Genoa.” European Planning Studies 3, no. 1: 3-23.

Le Galès, Patrick. 2016. “Neoliberalism and Urban Change: Stretching a Goode Idea Too Far.” Territory, Politics, Governance 4, no. 2: 154-172.

Le Journal de Seine Rive Gauche. 1991. “Naissance d’un grand projet.” No. 4.

Lehrer, Ute, and Jennefer Laidley. 2008. “Old Mega-Projects Newly Packaged? Waterfront Redevelopment in Toronto.” International Journal of Urban and Regional Research 32, no. 4 (December): 786-803.

Les Cahiers M2. 1994. No. 35.

Mairie de Paris. 2018. “ZAC Bercy-Charenton : Projet de Délibération, Exposé des Motifs.”

Nelson, Suzy. 2001. “The Nature of Partnership in Urban Renewal in Paris and London.” European Planning Studies 9, no. 4: 483-502.

Nez, Héloïse. 2012. "De l'expertise associative à la constitution d'un contre-pouvoir. Action collective et concertation à Paris Rive Gauche.” Espaces et Sociétés 151, no. 3: 139-154.

Ozdoba, Marie-Madeleine. 2013. "La mise en paysage du Front de Seine : de la ville du future à la ville durable (1960-2010).” Articulo 4: 1-18.

Pinson, Gilles. 2009. Gouverner la ville par projet. Paris: SciencePo Les Presses. 
Pinson, Gilles, and Christelle Morel Journel. 2016a. “The Neoliberal City—Theory, Evidence, Debates.” Territory, Politics, Governance 4, no. 2: 137-153.

Pinson, Gilles, and Christelle Morel Journel. 2016b. "Beyond Neoliberal Imposition: State-Local Cooperation and the Blending of Social and Economic Objectives in French Urban Development Corporations.” Territory, Politics, Governance 4, no. 2: 173-195.

Robert, Jean. 1995. “L'évolution des tissus urbains à Paris et à Londres pendant les années 80.” Bulletin de l’Association de géographes français 72, no. 3: 261-272.

Sabbah, Catherine. 2014. “Beaugrenelle, les secrets d’une renaissance.” Les Échos, June 4, 2014.

Savitch, H.V. 1988. Post-Industrial Cities. Princeton: Princeton University Press.

SEMAPA. 2018. “Paris Rive Gauche : Le programme.” Accessed July 20, 2018.

http://www.parisrivegauche.com/L-operation-d-urbanisme/Le-programme.

SemPariSeine. 2013. “Front-de-Seine: Une Nouvelle Impulsion Urbaine, Sociale et Économique.” Accessed July 20, 2018. http://www.sempariseine.fr/IMG/pdf/Plaquette_presentation_FDS_0313.pdf.

SemPariSeine. 2018. “Histoire du quartier.” Accessed July 20, 2018.

http://www.parisfrontdeseine.fr/le_front_de_seine_accueil.php.

Stevens, Quentin. 2006. “The design of urban waterfronts: A critique of two Australian 'Southbanks.”' The

Town Planning Review 77, no. 2: 173-203.

Storper, Michael. 2016. “The Neo-liberal City as Idea and Reality.” Territory, Politics, Governance 4, no. 2: 241-263.

Swyngedouw, Erik, Frank Moulaert, and Arantxa Rodriguez. 2002. "Neoliberal Urbanization in Europe: LargeScale Urban Development Projects and the New Urban Policy.” Antipode 34, no. 3: 542-577.

Vila Vázquez, José Ignacio. 2011. “Une analyse critique des ‘flagship projects’ urbains: Le cas de la bibliotheque nationale de France.” In New Trends in the renewal of the city, edited by M.J. Piñeira Mantiñán and N. Moore, 105-122. Santiago de Compostela: IDEGA.

\section{Footnotes}

1. In recent years, many SEMs have been converted to Établissements publics locaux (EPL), which are even more direct representations of local leadership as the private-sector investment in the entities have been eliminated. $\bullet$ 
2. That said, the national government's primary objective was to encourage decentralization of employment to the new towns (Godard 1973). $\boxminus$

3. Even though the BnF includes a museum, it is not much of a touristic destination; its primary purpose is to serve researchers. Thus while its architecture stands out—it towers over the area-it is not a major attraction. $\underline{-}$

4. The latest large tourism-related projects, for example, have been chosen for sites not along the river; the Philharmonie de Paris (2015) is at the city’s border with Pantin and the Paris Arena II (2024) will be on the city's border with Saint-Denis. This is not because of a lack of space; neither the last stage of the Paris Rive Gauche project (at Bruneseau) nor the Bercy-Charenton project, both of which have plenty of room, will include a major tourist amenity. $ヒ$

5. A similar dalle was planned for the Bercy area when it was under the design management of the national government (APUR 1974b), but this design was not carried through as the project took more than a decade to get off the ground. $\leftrightarrows$

6. The renovation of Front-de-Seine over the past ten years altered this dynamic by increasing retail activity on the street level. Unlike the way in which the project was first designed, the redevelopment "creates links between districts; the link between the river and the neighborhoods has become a priority” (APUR 2010, 139).

7. By the late 1990s, the city was increasingly focused on developing connections to the surrounding suburbs (APUR 2000). Construction is now underway on sections of Paris Rive Gauche that will link directly to Ivry’s street network, creating a walkable corridor under the périphérique ring road. This initiative should be understood as an element of the region's slow but steady efforts at creating a “metropole” and greater Paris-suburb cooperation. $ヒ$

8. Initial plans included more substantial connections than actually completed, including pedestrian bridges at Citroën, both to the waterfront and across the river, and creating a large platform over the highway at Bercy (APUR 1980; 1982; 1990).

9. Indeed, the left-wing governments in Paris increased the number of social housing units in the city by 65 percent (about 91,000 units) between 2001 and 2016; of these, a large share of new units were located in major developments such as Paris Rive Gauche (see APUR, Les chiffres du logement social à Paris en 2016, Note n. 119, December 2017). 